\title{
Think Pair Share Cooperative Learning Model to Improve Students' Poem Writing Skills
}

\author{
Andita Nella Pramiftasari \\ Universitas Negeri Surabaya \\ Surabaya, Indonesia \\ only.u.lee@gmail.com
}

\begin{abstract}
The aim of this research is to improve elementary school students' poem writing skills by implementing think pair share cooperative learning model. The design of the study is classroom action research. The subjects were students of Ngelom Sidoarjo State Elementary School. This research consists of three stages: planning, execution and observation and reflection. Data collection techniques used were observation and test student learning outcomes. Data collected were analyzed qualitatively. The results showed that in the first cycle, the learning achievement percentage is $100 \%$, the value of learning achievement is 91.17. In the second cycle, the learning achievement percentage is $100 \%$, while the value of learning achievement is 98.21. The classical result of poem writing in first cycle is $70 \%$ and in the second cycle is $90 \%$. Obstacles experienced in the first cycle can be solved in the second cycle. Based on the above explanation, it can be concluded that the implementation of cooperative learning model of think pair share type can improve the poem writing skills of fifth grade students of Ngelom Sidoarjo State Elementary School.
\end{abstract}

Keywords - cooperative learning model think pair share type; writing skill; poem.

\section{INTRODUCTION}

There are four language skills, they are listening skill, speaking skill, reading skill, and writing skill. In this research, we will focus on the writing skill. Writing is one of the language activities. To express their feeling and mind, writers use written language clearly, interestingly, and appealing to the reader.

In the fifth grade semester on theme one about things surrounding the students which has subtheme things shape and its characteristics that contains lesson 2 and 4 , is found the learning of writing poem. One of its basic competencies that must be mastered by fifth grade students are basic competency 3.4 about Digging information from poetry text and poem about nature disaster and also life of nation and state with teacher and friends help in the oral and written Indonesia Language by choosing and sorting out the standard vocabulary and basic competency 4.4 about Chanting and presenting the text of poetry and poem about natural disaster and also life of nation and state independently in the oral and written Indonesia language by choosing and sorting out the standard vocabulary.

Based on the writer observation about writing poem lesson in the fifth grade at Ngelom State Elementary School, it has been found the difficulty of the students in writing poem. The students have difficulty to decide which word is to use in "sampiran" sentences and make connection between "sampiran" and content of poem. The result of fifth grade students in writing poem is still below the minimum competence criteria. About 70 percent students have score below the minimum competence criteria.

The difficulty that are experienced by the students in writing poem is caused by students not reading enough so the students vocabulary is lacking and make them difficult to decide which word is used in "sampiran". Another factor because students rarely read poem works in books and the internet. In the writing poem lesson, the teacher usually asks students to write a poem individually. This matter makes students more difficult in writing poem. Based on that observation, the writer try to solve the problem by conducting a class action research entitled "The Implementation of Cooperative Learning Model Think Pair Share Type to Improve Students Poem Writing Skill". This is the implementation of think pair share to facilitate students in improving their skills in making poem. Students can work with a friend to make interesting poem. With the help of friends, students can share ideas, knowledge and motivation.

Based on the background described above, the research problems can be formulated as follows: (1) How is the implementation of poem writing skills learning by applying cooperative learning models of type think pair share to elementary school students? (2) What is the result of learning poem writing skills of elementary school students by applying cooperative learning models of type think pair share?

The implementation of this classroom action research is expected to provide several benefits, namely: (1) For the teacher, the results of this study are expected to provide suggestion on effective learning models in writing rhymes. (2) For other researchers, the results of this study are expected to be a reference for further research. (3) For schools, the results of the study are expected to provide suggestion in order to make improvement in the learning process for students and teachers so that the quality of education can improve.

Sanjaya (2006: 240) explains that cooperative learning is learning with small groups that are heterogeneous. Meanwhile, according to Slavin (in Rusman, 2012: 201) cooperative learning makes students active in groups, exchanging ideas with others without feeling threatened. From the opinions of 
experts, it can be concluded that cooperative learning is learning that encourages students to actively exchange ideas in heterogeneous groups. According to Trianto (2007: 61) think pair share is a type of cooperative learning designed to influence student interaction patterns. Based on the above opinion, it can be concluded that Think Pair Share is a learning that classifies students in pairs to influence student interaction patterns.

According to Julianto (2011: 41-42), the steps of Think Pair Share type learning are: Stage 1: Thinking, the teacher asks questions or issues related to the lesson, then students are asked to think about the question independently for a few moments. Stage 2: Pairing, the teacher asks students to pair up with other students to discuss what they have thought in the first stage. Interaction at this stage is expected to share answers if a question has been asked or to share ideas if a specific problem has been identified. Usually the teacher gives 4-5 minutes to pair up. Stage 3: Sharing, At this final stage the teacher asks the couple to share with the whole class what they have talked about. To make it effectively, it is done by taking turns in pair by pair and continued until about a quarter of the couples have had the opportunity to report.

Language has a central role in the intellectual, social, and emotional development of students and is a supporting success in learning all fields of study. Language learning is expected to help students get to know themselves, their culture, and other people's culture, express ideas and feelings, participate in the community that uses it, and find and use the analytical and imaginative abilities that exist within them (Depdiknas, 2006: 317)

Language skills have four components, namely listening skills, speaking skills, reading skills, and writing skills (Tarigan, 2008: 1). In the writing skills, mastery of various linguistic elements and elements outside of language and content must be intertwined in such a way as to produce consistent and coherent writing (Iskandar wassid and Sumendar, 2009: 227).

Sumarjo (in Komaidi, 2011: 5) states that writing is a process of giving birth to writings containing ideas. Usually done spontaneously, but there are also many times that have made corrections and rewrites. Writing is a process of expressing thoughts, ideas, or opinions about something, responses to a statement, desire, or expression of feelings by using written language (Rofi'uddin, 1998: 159). From the above opinion, it can be concluded that writing is the process of expressing thoughts and opinions that give birth to writings containing ideas.

Tarigan (2008: 22-23) explained that writing is very important for education because it makes it easy for students to think. It can also help us think critically. It can also make it easier for us to feel and enjoy relationships, deepen our responsiveness or perception, solve the problems we face, arrange sequences by experience.

Nadjua (no year: 24) states that poem is a type of old poetry in one verse consisting of four lines and rhymes a-b-ab. The first and second arrays are "sampiran", while the third and fourth arrays are contents. "Sampiran" has no meaning, only the rhyme is taken. From the above opinion about poem, it can be concluded that poem is an old poetry which consists of four lines that have "sampiran"and fill and rhyme a-b-a-b. According to Sumarlikah (2006: 27), poem is an old poetry consisting of four lines in one verse. The first and second lines are "sampiran", while the third and fourth rows are the contents.

Characteristics poem according to Nadjua (no years: 24): (a) Each stanza consist of 4 lines/rows. (b) Each row/array consists of 4-5 words. (c) The verse a-b-a-b (d) A good poem is not just have a late rhyme but a middle rhyme also. (e) the first two and second lines are "sampiran", while the third and fourth line are the content of the poem. In assessing poem there are several aspects used to assess writing poem. Sarinah (2013) stated there are four aspects in assessing writing poem: (1) four lines or arrays in one stanza. (2) there are 8-12 syllables in a row or array. (3) ab-ab or aa-aa verse. (4) the first and second lines are called as "sampiran", the third and fourth lines are called as contents. Satriana (2014) stated that there are four aspects in assessing writing poem, they are: (1) completeness the amount of syllables in a single array. (2) completeness the amount of syllables in one stanza. (3) the precision of rhyme. (4) suitability of "sampiran"and content with the theme. While Qomariah (2010) stated that there are three aspects in assessing poem: (1) aspect of the suitability form. (2) the accuracy of the content. (3) aspect of creativity. Based on the opinion above, therefore the aspects that are used to assess writing poem are: (1) the amount of syllables in a lines. (2) the amount of line in the stanza. (3) rhyme in the poem stanza. (4) the suitability of the poem and the content.

\section{METHOD}

This research is entitled "The Implementation of Cooperative Learning Model Thing Pair Share type to Improve the Students' Poem Writing Skill'. The research methodology that is used in this study is descriptive qualitative research. According to Arikunto (2006:12) qualitative is a research activity that does not use number in collecting and providing interpretation of the result. This research used a classroom action research design. Classroom action research is a research conducted by teachers in their own class through self-reflection with the aim to improve their performance so that the students learning outcome will increase (Wardhani, 2008.1.15).

The subject of this research are teacher and fifth grade students of Ngelom State Elemtary School with 30 students consisting of 16 male students and 14 female students. The reason for choosing the subject is that the teacher has never applied poem writing learning using the think pair share type and around $70 \%$ of fifth grade students are still lacking in skill in making poem.

In classroom action research there are four stages, namely planning, implementing, observing, reflecting. The activity is part of cycle I. Then from the results of the reflection of cycle I if found things that are not appropriate then it will continue in cycle II. 


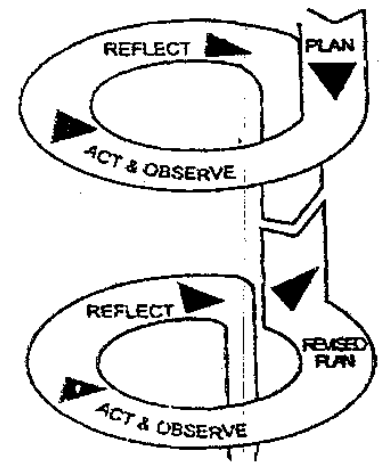

Figure 1. Kemmis and Taggart Chart (adapted from Arikunto, 2006: 93)

Data is collected during the learning process. Data was collected by researchers and observers (peers) who observed the learning process. The following data must be collected by researchers and observers:

(a) Data from the implementation of learning.

Percentage of implementation of learning activities

$P=\frac{\mathrm{Nk}}{\mathrm{N}} \times 100$

(Arikunto,2006:281)

Explanation:

$\mathrm{P}=$ percentage

$\mathrm{Nk}=$ activities carried out

$\mathrm{N}=$ All activities carried out

Assessment criteria for the percentage of implementation of learning activities is as follows:

$$
\begin{array}{ll}
\geq 80 \% & =\text { Very Good } \\
60 \%-79 \% & =\text { Good } \\
40 \%-59 \% & =\text { Enough } \\
20 \%-39 \% & =\text { Less } \\
<20 \% & =\text { Very Less }
\end{array}
$$

Achievement in learning activity

$\mathrm{N}=\frac{\text { Score obtained }}{\text { Maximum Score }} \times 100$

Criteria for assessment of the achievement in learning activity is as follows:

$$
\begin{array}{ll}
\geq 80 \% & =\text { Very good } \\
60 \%-79 \% & =\text { Good } \\
40 \%-59 \% & =\text { Enough } \\
20 \%-39 \% & =\text { Less } \\
<20 \% & =\text { Very less }
\end{array}
$$

(b) Data of students learning outcomes in writing rhymes.

$$
\text { Score }=\frac{\text { Total score }}{\text { Maximum score } x \text { number of aspects of assessment }}
$$

To determine the percentage of classical completeness, the following formula is used:

$$
\begin{aligned}
& \mathrm{P}=\frac{\sum \mathrm{x}}{\mathrm{N}} \mathrm{x} 100 \% \\
& \text { (Arikunto,2006:189) } \\
& \begin{aligned}
\text { Explanation : } \\
\mathrm{P} \quad=\text { percentage } \\
\sum \mathrm{x} \quad=\text { Number of students who are completed } \\
\mathrm{N} \quad=\text { Number of all the students }
\end{aligned}
\end{aligned}
$$

\section{RESUlt AND DiscUSSION}

This study uses a think pair share type cooperative learning model to overcome students' difficulties in writing poem by exchanging ideas with other people or friends. The study was conducted in two cycles with the following results:

\section{Cycle I}

Classical Completeness:

$$
\begin{aligned}
\mathrm{P} & =21 / 30 \times 100 \% \\
& =70 \%
\end{aligned}
$$

Percentage of implementation of learning

$$
\begin{aligned}
\mathrm{P} & =\frac{\mathrm{Nk}}{\mathrm{N}} \times 100 \% \\
\mathrm{P} & =\frac{17}{17} \times 100 \% \\
& =100 \%
\end{aligned}
$$

Achievement in learning activity

$$
\begin{aligned}
\mathrm{N} & =\frac{\text { Score obtained }}{\text { Maximum Score }} \times 100 \\
& =91.17
\end{aligned}
$$

Cycle II

Classical Completeness:

$$
\begin{aligned}
\mathrm{P} & =27 / 30 \times 100 \% \\
& =90 \%
\end{aligned}
$$

Percentage of implementation of learning

$$
\begin{aligned}
\mathrm{P} & =\frac{\mathrm{Nk}}{\mathrm{N}} \times 100 \% \\
\mathrm{P} & =\frac{14}{14} \times 100 \% \\
& =100 \%
\end{aligned}
$$

Achievement in learning activity

$$
\begin{aligned}
\mathrm{N} & =\frac{\text { Score obtained }}{\text { Maximum Score }} \times 100 \\
& =98.21
\end{aligned}
$$


Based on the data above, we can discuss the data as follows:

Cycle I

In cycle I, the classical completeness obtained is $70 \%$. The classical completeness is in good category (Djamarah, 2002: 121). The classical completeness has not reached the specified indicator that is $75 \%$, thus, it needs to be improved in cycle II. The implementation of learning is $100 \%$ with a very good category (Sudjana, 2008: 131). This achievement shows that the teacher has carried out the learning in accordance with the designed learning. Achievement of learning implementation is 91.17 with very good categories (Sudjana, 2008: 131)

\section{Cycle II}

In cycle II, the classical completeness obtained is $90 \%$. The classical completeness is in a very good category (Djamarah, 2002: 121). The classical completeness has reached $75 \%$ indicator even exceeding the indicator target. The implementation of learning is $100 \%$ with a very good category (Sudjana, 2008: 131). This achievement shows that the teacher has carried out the learning in accordance with the designed learning. The achievement of learning implementation is 98.21 with a very good category (Sudjana, 2008: 131). The teacher corrects the deficiencies in cycle I so that it increases in cycle II.

\section{CONCLUSION}

The implementation of learning by applying Cooperative Learning Model Thing Pair Share type on poem writing lesson can increase the value of learning achievement from 91.17 in cycle I to 98.21 in cycle II. The percentage of learning implementation data reaches $100 \%$ in cycle I and cycle II.

The result of students' poetry writing learning has increased. This can be seen from the classical completeness of cycle I by $70 \%$ to $90 \%$ in cycle II.

\section{References}

[1] Arikunto, Suharsimi. 2006. Prosedur Penelitian Suatu Pendektan Praktik. Jakarta : Rineka Cipta.

[2] Arikunto, Suharsimi. 2009. Dasar-Dasar Evaluasi Pendidikan. Jakarta Bumi Aksara.

[3] Arikunto, Suharsimi. 2010. Dasar-Dasar Evaluasi Pendidikan. Jakarta : Bumi Aksara.

[4] Depdiknas. 2006. Pengembangan Silabus dan Rencana Pelaksanaan Pembelajaran. Jakarta : Depdiknas.

[5] Djamarah, Syaiful Bahri. 2002. Strategi Belajar Mengajar. Jakarta : PT Rineka Cipta.

[6] Iskandarwassid dan Dadang Sumendar. 2009. Strategi Pembelajaran Bahasa. Bandung : PT Remaja Rosda Karya.

[7] Julianto, dkk. 2011. Teori Dan Implementasi Model-Model pembelajaran Inovatif. Surabaya : Unesa University Press.

[8] Komaidi, Didi. 2007. Panduan lengkap menulis kreatif. Wates : Sabda.

[9] Nadjua. Tanpa Tahun. Buku Pintar Puisi dan Pantun. Surabaya : Triana Media.

[10] Rofi'uddin Ahmad dan Darmiati Zuhdi. 1988. Pendidikan Bahasa dan Sastra Indonesia di Kelas Tinggi. Depdikbud : Direktorat Jenderal Pendidikan Tinggi.

[11] Rusman. 2012. Model-Model Pembelajaran. Jakarta : PT Raja Grafindo Persada.

[12] Sanjaya, Wina. 2006. Strategi Pembelajaran. Jakarta : Kencana.

[13] Santosa, Puji. 2009. Materi dan Pembelajaran Bahasa Indonesia SD. Jakarta : Universitas Terbuka.

[14] Sarinah.2013. Kemampuan Menulis Pantun Siswa Kelas VII Sekolah Menengah Pertama Negeri 2 Senayang Tahun Pelajaran 2012/2013, (online), (http://jurnal.umrah.ac.id/wp-content/uploads/2013/08/Sarinah090388201292.pdf, diakses 25 Pebruari 2015).

[15] Satriana, Dina.2014. Kemampuan Menulis Pantun Menggunakan Teknik Objek Langsung Siswa Kelas VII SMPN 2 Bukittinggi, (online), (http://jurnal.umsb.ac.id/wp-content/uploads/2014/10/DINASATRIANA.pdf, diakses 25 Pebruari 2015).

[16] Solchan T. W,dkk. 2008. Pendidikan Bahasa Indonesia di SD. Jakarta : Universitas Terbuka.

[17] Sudjana, Nana. 2008. Penelitian Hasil Proses Belajar Mengajar. Bandung : PT Remaja Rosda Karya

[18] Sumarlikah. 2006. Jartra (Belajar Sastra). Surabaya : Farhas

[19] Tarigan, Henry Guntur. 2008. Menulis Sebagai Suatu Keterampilan Berbahasa. Bandung : ANGKASA

[20] Tarigan. 2008. Model-model pembelajaran inovatif. Surabaya:Unipres UNESA.

[21] Trianto. 2007. Model-Model Pembelajaran Inovatif Berorientasi Konstruktivistik. Jakarta : Prestasi Pustaka. 